\title{
Development of the University Image Positioning Methods in the Context of its Marketing Strategy
}

\author{
Submitted 20/08/19, $1^{\text {st }}$ revision 23/09/19, $2^{\text {nd }}$ revision 19/10/19, accepted 25/11/19 \\ Baturina O.E., ${ }^{1}$ Erokhina T.B., ${ }^{2}$ Fedko V.P., ${ }^{3}$ Shaginyan S.G. ${ }^{4}$
}

\begin{abstract}
:
Purpose: The note aims to study the steps actions algorithm in the positioning of university image, based on the method of using official media sites and searching systems and social networks.

Design/Methodology/Approach: Today in the digital economy, higher educational establishments should take advantage of the opportunities arising from the involvement of the digital infrastructure in the process of their functioning. The positioning of an existing service or product usually takes the form of repositioning. The basis of the methodic apparatus of this study is the method of using official media sites and searching systems and social networks, which is used in the preparation of the steps algorithm in the university's image positioning.

Findings: The steps algorithm in the university image positioning is based on the method of using official media sites and searching systems and social networks. This method is developed by the authors and substantiated for the implementation in the sphere of higher educational establishments.

Practical implications: In practice, we are talking about the formation of a mechanism function to provide the basic steps necessary to build an algorithm of the higher educational establishment image positioning.

Originality/value: The concept "positioning" is the most often associated with persons (politicians, "stars") and companies engaged in the production or promotion of goods or services and positioning themselves to create their image, but not about the university positioning.
\end{abstract}

Keywords: Positioning, university image, marketing research, rating of universities, report.

JEL Codes: M31, M39.

Paper type: Commentary note: Image Positioning.

\footnotetext{
${ }^{1}$ Post-graduate, Oryol State University named after I.S. Turgenev, Russia, kosarevaoe@yandex.ru

${ }^{2}$ Professor Chair of "Marketing and advertising" Rostov State University of Economics, Rostov-on-Don, tberokhina@yandex.ru

${ }^{3}$ Professor Chair of "Marketing and advertising" Rostov State University of Economics, Rostov-on-Don,vf42@yandex.ru

${ }^{4}$ Professor Chair of "Economics and management "Rostov state University of Railways", Rostov-on-Don, em@kaf.rgups.ru
} 


\section{Introduction}

Positioning a new service (a new "form" of a previous service) or a new product in the minds of buyers or repositioning an existing service or product in the market involves a number of steps. We will show the steps algorithm in the university image positioning, based on the method developed in this study. It is connected with using official media sites and searching systems and social networks.

There are many methods of positioning by which consumers are impressed that this product is created specifically for them to be identified with their ideal. And, again, they were developed to position a person or a product (service), although most of them can be used to some extent for the university. We propose to consider the method specifically developed for the positioning both universities and companies, goods, services, individuals.

\section{Materials and Methods}

The specificity of media, including the external human expansion is investigated in the work by McLuhan (2008). Fundamental and applied issues of the product positioning in the market are investigated in the works by Danilov (2010). In 2010 the criteria for the universities rating by the Rating agency "EXPERT RA", the National Research University "Higher School of Economics" together with the RIA "News", the All-Russian public organization "Business Russia", the Federal Agency for education, the Publishing house "Businessman" ("Kommersant"), the independent Agency "Reuters" and others were taken on the portal (TASS, 2012). Nevertheless, despite the high degree of the problem individual components elaboration, is still insufficient and fragmentary in and requires further research (Gorina, 2016).

Our method is to analyze the data (positive, negative, neutral) about the university and its competitors in searching systems, official media sites and social networks. This is the most modern, affordable method and it reflects the actual reality. The method makes it possible to identify the university position through the Association of recognition, fame, frequency of its abbreviation use and access to its data, and also to identify the position of its main competitors on the official websites of local media and searching systems and social networks. Visually, the method shows where the target audience can most often find the information about our university and universities-competitors and take corrective measures on the positive recognition and presenting unique, distinctive features of the university (Pastukhov et al., 2018).

Thus, the target audience through the well-known, modern, popular ways of searching for some information such as official media sites, searching systems and social networks can get some information about the university and compare it with competitors. And on this basis, the university will be presented in a positive way.

\section{Results and Discussion}


Step 1: To define a set of competitive services:

The positioning analysis is carried out almost at all the levels: the university as a whole, faculties, departments and specialties, business units. Such an analysis helps to determine how a company as a whole or a business unit is positioned relating to its competitors.

At the level of the profession choice, the analysis includes consumers' perception of other specialties. Suppose, for example, that an organization is going to bring a new specialty to market. The new service will have to compete with other universities and other specialties. To assess the position of a new specialty in the market, the specialist in marketing must get an idea of the new service perception by consumers regarding the possible interchangeable specialties by a variety of defining attributes, which corresponds to stages 3 and 4 of the positioning process (Danilov, 2010).

When competitive universities introduce several specialties to the market, it can be useful to analyze the positioning of the service or image of the university as a whole to understand better how different universities are attractive for consumers, to position new services or the university as a whole, or to reposition available services and identify sources of new competitive opportunities. Regardless of the positioning level analysis, the choice of competing services is very important. Universities that neglect important interchangeable specialties or potential competitors run the risk of being hit surreptitiously by unforeseen competitors.

\section{Step 2: Set the defining elements:}

The university positioning is based on a number of reasons. In theory, consumers can use multiple elements to evaluate services provided by the university or the university as a whole, but as usual the number of these elements is small, it is because of consumers can consider only those they are aware of. The more variables elements are used in the positioning, the higher is the probability of error on the part of consumers. Positioning activity should be as simple as possible and complexity should be avoided at all. When using one or more elements as a basis for the university positioning, it is important to realize that the importance attached to these elements is often different. In the positioning analysis, specialists in marketing must rely primarily on the crucial elements. The specialists in marketing can find out these parameters after some marketing research. This brings us to step 3 .

Step 3: Gather the information about how consumers perceive competing services: At this stage, it is important to know what elements are decisive for the analyzed target market. The specialists in marketing also has to find out how the services of competitors are evaluated by potential consumers on these elements. Typically, these knowledge about the market is collected through, for example, interviews in focus groups conducted with the purpose of identifying the decisive elements. As usual, this information about the market is collected through, for example, interviews in focus groups conducted with the purpose to identife the defining elements. This is followed by the quantitative analysis, such as a survey of consumers' perceptions, to gather the 
information on how competing products are evaluate on individual elements (Danilov, 2010).

Step 4: Analyze the current positions of services in the competitive set:

At this stage, it is important to understand the university positioning, providing a visual representation of the university positions and its closest competitors. There are many positioning methods, most of which we discussed before. But they were designed to position a person or a product (service). Although a number of them can be used to some extent for the university positioning, we propose to use the method specially designed by us for the university positioning, as well as to use it for the positioning of companies, goods, services, persons.

The main provisions of our method are the use of official media sites and searching systems and social networks. And at the $4^{\text {th }}$ step of the university image positioning algorithm (it means the analysis of the current positions of services in a competitive environment) we offer the following:

1. To determine the mentions frequency about the analyzed university and its closest competitors on the official websites of local media, searching systems and social networks.

2. During the study to identify in the selected three main sources of the necessary information -social networks, local media and searching systems - errors in giving up the amount of the information.

To eliminate errors by using the following method to find them:

$>$ in social networks and local media errors to count by hand as the largest number of search results here is not so large;

$>$ errors in the searching systems are calculated as follows: the results here cannot be calculated by hand, as the query by the university name, the searching system can include similar universities in other cities, activity, and even names consonant with the city of the university location.

The number of errors should not exceed 5\%. By eliminating errors, $\%$ or its absolute value, you get the underlying data system. For greater clarity, it is necessary to divide the information into 3 blocks: The first block is official sites of local media, the second block is searching systems, the third block is social networks and present the information in the form of a visual diagram reflecting the university current position in comparison with its competitors in the studied informational blocks. Our method makes it possible to determine the university position through the Association of recognition, fame, frequency of access to its data and the university abbreviation use and its main competitors on the official websites of local media and searching systems and social networks. Visually, the method shows where the target audience can most often find the information about our university and universities-competitors and take 
appropriate corrective measures on positive recognition and present unique, distinctive features of the university. Thus, the target audience through the wellknown, modern, popular ways of searching for the information, such as official media sites, searching systems and social networks, can learn about this university and compare it with its main competitors (Divanova et al., 2019). And on this basis, the university will be associated with the positive qualities of some competitors and in a winning position at the background of others.

Step 5: To determine the most preferred elements combinations for consumers:

For example, respondents can get a task to come up with the ideal training for a particular specialty or the ideal work of the university as a whole, taking into account the ideal elements combination (from the point of view of a consumer). Which university is considered to be the closest to the ideal and why. After that, respondents get a task to evaluate the chosen speciality or university as a whole by eight elements and also to indicate which of the eight elements they primarily pay attention to and why.

Another method of evaluating consumer preferences is the statistical method. Consumers are asked about their preferences relating to the variety of real or hypothetical work of the university as a whole, each of them has its own features. Analyzing the resulting data, it is possible to make a conclusion which of several attributes are more important than others. These results can then be used in the positioning analysis (Danilov, 2010). The price use as one of the indicators of the positioning system or as a key element by which the educational service is positioned is not always acceptable, because first, the price is easily imitated by competitors; second, statement such as training in some university is cheap, sometimes is not very credible, unless the university is state university, and then the impression of inferior education is created. It is reasonable to position the univerversity basineg on more stable factors of the unification and allow the price to act more masterly (Sutarso et al., 2017).

One more way is to analyze different university ratings. For example, the rating of universities of the British edition "Times Higher Education" (THE). However, its main criteria are not suitable for evaluating the quality of education in the Russian universities. This opinion was expressed in an interview with ITAR-TASS by the head of the analytical service of the Russian Union of rectors Boris Derevyagin, commenting the results of the new THE rating, in where only Moscow State University named after M.V. Lomonosov and Moscow Institute of Engineering and Physics made it to the top 300 universities, but failed to enter the top hundred. The criteria that the authors of the rating presented as the main ones, explaining the low positions of Russian universities, is not so strong" he said (TASS, 2012).

To discuss what needs to be adjusted in the rating and whether it is necessary to do it at all, in this case, it is meaningless, it is important to note that every rating serves a certain purpose. In our case, it should serve the development of Russian universities, 
but the goals of their development are not the growth of state funding or the publication about scientific discoveries in English. Universities should serve, first of all, "the development of new social and economic relations, the growth of the country welfare in which they are located, universities should become a meeting place for ideas and their solutions that serve for the good of the people" (McLuhan, 2008).

In this regard, Russia needs its own rating and its own mechanism for evaluating its universities. The idea to develop the Russian rating of universities was supported by many rectors. At the same time, the head of the Ministry of education and science of the Russian Federation at that time Dmitry Livanov said that the Ministry itself did not plan to make such a rating, because it was the task rather for the media and public organizations. Therefore, for analysts who determine the preferences of consumers in the positioning analysis, it is possible to advise, for example, quantitative assessments of the universities in the form of various ratings compiled by (TASS, 2012):

- EXPERT RA Rating Agency";

- National Research University "Higher School of Economics" together with RIA "News" (Novosti);

- All-Russian public organization "Business Russia";

- The Federal Agency for Education;

- The Publishing house "Businessman" (Kommersant);

- The Independent Agency "Reitor".

The information by the rating Agency "EXPERT RA" is based on statistical indicators, large-scale surveys among 4 thousand respondents: employers, representatives of academic and scientific circles, students and graduates. The rating methods are based on the opinions expressed by representatives of the leading Russian Federations universities. The ratings by the Higher School of Economics and RIA "News" (Novosti) are based on the exam scores of students enrolled in 2011 and 2010 for the first year of bachelor/specialist degree. Rating of the LLC "Business Russia" evaluates Russian universities in terms of demand for their graduates in the labour market. The rating by the Federal Agency for Education is based on official data received from the administrations of universities (form 2nk). The FAO rating considered parameters such as: the teaching staff, the number of students in different forms of education, students from other countries, the volume of research, publishing, providing students with hostels, dispensaries, etc. The calculation of the results was made considering the university branches.

The rating of the universities by the publishing house "Businessman" (Kommersant) was based on a survey of the largest Russian companies, which provided information about several thousand young professionals hired by them. The Independent Rating Agency in the field of education "Reitor" conducted rating studies of universities on the criteria of public evaluation, based on its own sociological research and official information of state bodies (Guskova et al., 2016). 
Also, there is a rating of state universities on the average exam score. This is a joint project of HSE and RIA "News" (Novosti). Experts from the HSE performed the monitoring of state universities in Russia in terms of enrolled students in them. On its basis, a rating on the average exam score for all the state universities in Russia was made. The National rating of Russian universities is the most famous one. Informinvest, a subsidiary of Interfax, has developed an independent system for evaluating and rating Russian universities. The system is based on the following main indicators: educational activity of the university (weight in evaluation - 0.2); the research activity of the university (0.2); the socialization activity of the university (0.15); the international activity of the university $(0.15)$; the brand of the university $(0.15)$; the public opinion about the university activity (0.15) (TASS, 2012).

Step 6: To consider the correspondence between the preferences of the consumer segments and the current position of the services provided by the university:

Due to the fact that the differences between the ideal points of different consumers groups of educational services (parents, school leaver, students as potential customers, enterprises as final consumers, the Ministry of education as a customer and regulatory authority over the service quality) reflect the differences in the benefits they seek. At the same time the market positioning analysis determines some market segments, as well as the perceived position of various services in the field of education. When the criteria that influence the opinion formation in each segment of the elements are defined, their sum will be the ideal result of the university positioning (Bondarenko $e t$ $a l ., 2019)$. And the difference between them and the image elements development will be the factor that first of all it is important to pay attention to positioning the university image. The $6^{\text {th }}$ Step helps to identify the missing criteria on the elements that should be paid attention to when positioning to meet the needs poorly met by current competitors.

Step 7: To form a positioning report for the management making the decision on the marketing strategy:

The final decision on how to reposition the university image is made. In our case, it is necessary to work with the official website, social networks and searching systems, local media. It is necessary to make groups in social networks for dialogue between representatives of higher educational eatablishments and potential consumers of educational services of this higher educational establishments. In searching systems, it is important to do all your best to eliminate the negative information about the university. Representatives of the university should work steadily with local media on the fact of holding events that affect the university image. The official website should be designed in such a way that all the necessary information would be presented in the logical accessibility. And also all these data should be connected with each other. We will talk in details about this in the next paragraph.

Reports play a few important roles. They provide guidance for the staff and the development of the university image about what kind of elements should be changed or added to those that already are (Akopova et al., 2017). The positioning report forms 
should be the basis of the marketing strategy. When sometimes these reports are used at the business level, they express the strategic direction of the company in all the areas. To promise the target market a certain kind of the positioning or value is one thing, but to realize such a promise is another. Clear and concise positioning statements can play an important role in the successful implementation of the intended strategy (Danilov, 2010).

\section{Conclusion}

Since there are no real differences between educational services for the consumer, it is difficult to achieve success. When the necessary service positioning is determined, it is necessary to strengthen it. Those responsible for developing the strategy should understand what is planned for the services and how it will be positioned in relation to other educational services of competitors. Then they write a positioning report, which is a summary that identifies the target market for which the service is intended, as well as outlines the unique benefits of using this service.

\section{References:}

Akopova, S.E., Przhedetskaya, V.N., Taranov, V.P., Israilova, A.E. 2017. Marketing aspects of Russia-The European Union Cooperation in the Field of Education. European Research Studies Journal, 20(1), 267-275.

Bondarenko, V.A., Efremenko, I.N., Larionov, V.A. 2019. Marketing Strategy for Hotel and Tourist Complex Companies. International Journal of Economics and Business Administration, 7(S1), 388-394. DOI: 10.35808/ijeba/283.

Danilov, V.V. 2010. Goods Positioning in the Market. Moscow, The Book Laboratory, 69.

Diyanova, S.N., Guba, E.N., Guseva, M.V., Popova, T.S. 2019. Strategies and Innovations in Modern Trade Marketing. International Journal of Economics and Business Administration, 7(S1), 494-500, DOI: 10.35808/ijeba/295.

Gorina, P.A. 2016. Issues and Prospectives of the Educational Service Market Modernization. European Research Studies Journal, 19(3) Part B, 227-238.

Guskova, D.N., Vdovin, M.S., Krakovskaya, N.I., Slushkina, Yu.Yu. 2016. The Quality of Education as a Primary Concern of the Sustainable Development. European Research Studies Journal, 19(3) Part B, 239-257.

McLuhan, M. 2008. Understanding Media: External Extensions of a Person. Zhukovsky, 94.

Sutarso, Yu., Halim, R.E., Balqiah, T.E., Tjiptoherijanto, P. 2017. The Role of Co-creation Activities, Trust and Gender on Higher Education Marketing Performance. European Research Studies Journal, 20(3A), 825-845.

Pastukhov, V.A., Kliman, N.S. and Alekseev, D.S. 2018. Tendencies of Interaction between Russian Universities and Companies Implementing Innovative Development Programs. European Research Studies Journal, 21(1), 686-707.

TASS. 2012. The Times rating criteria are not suitable for evaluating the quality of Russian education, according to the Union of rectors. Available online: http://itartass.com/obschestvo/621432.

Terenina, I.V., Ovanesyan, N.M., Khan, R.S., Fedosenko, A.A. 2019. Marketing Activity in the Context of the Digital Economy. International Journal of Economics and Business Administration, 7(S1), 16-25, DOI: 10.35808/ijeba/248. 